\title{
IMPAIRMENT OF RAM SPERM-HYALURONAN BINDING ABILITY BY THE FREEZING EXTENDER
}

\author{
DIMINUIÇÃO DA CAPACIDADE DE LIGAÇÃO DOS ESPERMATOZÓIDES DE CARNEIRO \\ AO ÁCIDO HIALURÓNICO INDUZIDA PELO DILUIDOR DE CONGELAÇÃO
}

\begin{abstract}
Marques, C.C.; Barbas, J.P.; Horta, A.E.M.; Baptista, M.C.; Pereira R.M. e Cavaco-Gonçalves, S.*
Instituto Nacional de Investigação Agrária e Veterinária (INIAV, I.P.). Vale de Santarém. Portugal. *sandracavaco1@gmail.com
\end{abstract}

AdDitionAl KEYWORDS

Ram semen extenders. Fertility.

\section{SUMMARY}

The ability of ram sperm to bind to hyaluronan coated slides (HBS, \%) was tested on fresh (FS) and chilled semen (CS) diluted with skimmedmilk based extender (CS-SM), chilled (CS-EY) and frozen-thawed (FTS-EY) semen diluted with tris-glycerol-egg-yolk based extender. The $\%$ of HBS (motile bound sperm/all motile sperm) was similar in FS and CS-SM groups (73,6 \% vs. 71,2\%) both significantly higher than CS-EY (25\%) and FTSEY $(29,7 \%)$ groups. Progressive individual motile sperm (IMS) of the FTS-EY group was the lowest $(21,7 \%)$, and no differences were found among FS (63,3\%), CS-SM (55 \%) and CS-EY ( $48,3 \%)$. IMS was positively correlated with $\mathrm{HBS}(r=0,62 ; p<0,03)$. Although needing confirmation on a larger number of animals, the freezing extender used in the present work disrupted the mechanism of sperm hyaluronan binding prior to the freezing-thawing, suggesting a close relationship between this finding and lower fertility rates following artificial insemination with frozen-thawed semen.

\section{RESUMO}

Avaliou-se a capacidade de ligação dos espermatozóides de carneiro ao ácido hialurónico (\% HBS), no sémen fresco (FS) e refrigerado (CS) diluído com leite de vaca desnatado (CS-SM) e sémen refrigerado (CS-EY) ou e congelado (FTS-EY) diluído com um diluidor de tris-glicerol-gema de ovo. A \% de HBS (espermatozóides móveis ligados/total de espermatozóides móveis) nos grupos FS e CS-SM foram semelhantes (73,6 \% vs. $71,2 \%)$, ambas

\section{PalaVRas ChaVe ADICIONAIS}

Diluidores de sémen de carneiro. Fertilidade.

significativamente superiores aos grupos CS-EY (25\%) e FTS-EY (29,7\%). A diferença entre os grupos CS-EY e FTS-EY não foi significativa. A percentagem de motilidade individual progressiva(IMS) mais baixa foi obtida no grupo FTS-EY $(21,7 \%)$, não havendo diferenças entre os grupos FS $(63,3 \%)$, CS-SM (55 \%) e CS-EY (48,3\%). Verificou-se uma correlação positiva entre a IMS e a HBS ( $r=0,62$; $p<0,03$ ). Embora necessitando confirmação num maior número de animais, o diluidor de congelação utilizado perturbou, previamente à congelação, a ligação dos espermatozóides ao ácido hialurónico, sugerindo a existência de uma relação com as baixas taxas de fertilidade obtidas na ovelha após a IA com sémen congelado.

\section{INTRODUCTION}

Misoprostol administration to synchronized ewes, $48 \mathrm{~h}$ after sponge removal, increased the content of hyaluronan in the vagina and cervix epithelial layer, advancing in required cervical transformations from 72 to $54 \mathrm{~h}$ (AI timing) after sponge removal (Leethongdee et al., 2007). Although misoprostol administration during synchronized oestrus failed to increase the proportion of intracervical inseminations, fertility increased significantly when using CS, but non-significantly when FTS was used (Horta et al., 2010; Barbas et al., 2013). When frozen-thawed semen was 
used in Saloia ewes, the fertility increase was of smaller magnitude and non-significant (Barbas et al., 2013).

Those findings suggest that misoprostol treatment could be associated to a higher hyaluronan concentration in the cervix and vagina, increasing sperm adhesion to vaginal and cervical wall and so the number of sperm available for fertilization. Lower magnitude in fertility increase when using FTS suggests that the freezing-thawing process or the extender may affect the misoprostol mediated sperm hyaluronan binding mechanism.

Sperm-hyaluronan binding assays identify motile sperm in human, through binding of HABP1 (Ghosh et al., 2002) and CD44 (Bains et al., 2002) membrane proteins to hyaluronan in the epithelial extracellular matrix of genital tract, and have been used for characterization and selection of viable sperm to fertilize in vitro mature oocytes.

The aim of this work was to evaluate the effect of different extenders for chilling and freezing upon the capacity of ram sperm to bind hyaluronan.

\section{MATERIAL AND METHODS}

Weekly collected semen ejaculates $(n=3)$, from one fertile Portuguese Saloia ram were in vitro tested for hyaluronan bound sperm (HBS). Four experimental groups were considered: fresh semen(FS); chilled semen diluted with a skimmed milk based extender (CS-SM); chilled (CSEY) and frozen-thawed semen (FTEY) diluted with an egg yolk + glycerol based extender. Semen collected by artificial vagina was immediately incubated at $28{ }^{\circ} \mathrm{C}$ and scored for volume, mass motility, sperm concentration by spectrophotometry, and percentage of progressive individual motile sperm (IMS) under microscope observation (400x). IMS was reevaluated in samples of FS, CS-SM and CS-EY after chilling, and of FTS-EY after thawing (Barbas et al., 2013). In the FS group, $10 \mu \mathrm{L}$ of semen were diluted $\left(24 \times 103 \mathrm{spz} \mathrm{mL}^{-1}\right)$ in synthetic oviductal fluid medium (SOF, Tervit et al., 1972) supple- mented with $2,5 \mathrm{mg} \mathrm{mL}^{-1}$ glucose (SOF-g, the only medium allowing ram sperm to bind hyaluronan, $270 \mathrm{mOsmol} \mathrm{L}-1$, 7,2-7,4 $\mathrm{pH})$ and incubated at $28{ }^{\circ} \mathrm{C}(30 \mathrm{~min})$. The remaining fresh semen was equally divided in two aliquots: CSSM group where semen was diluted to 1,2 spz mLx109 and chilled at $4{ }^{\circ} \mathrm{C}$ for 60 minutes in a refrigerated chamber; and the CS-EY and FTS-EY groups, where semen was diluted to the same concentration (Marques et al., 2006) and refrigerated at 4 ${ }^{\circ} \mathrm{C}$ for 90 minutes. In FTSEY group, semen was frozen in liquid nitrogen vapours before immersion into LN2. After dilutions, semen was packed in 0,25 mL Cassou mini-straws (300x $106 \mathrm{spz}$ ). In each group, samples from 3 ejaculates were tested for their ability to bind hyaluronan coated slides (HBA ${ }^{\circ}$, SpermHyaluronan Binding Assay, Biocoat, Inc, supplied by ORIGIO). Prior to counting \% HBS under contrast phase microscopy (400x), sperm samples $(10 \mu \mathrm{L})$ from the chilled and thawed groups were further diluted (SOF-g) to a final concentration $(24 \times 103)$ and incubated at $28{ }^{\circ} \mathrm{C}$ (30 minutes). Samples $(10 \mu \mathrm{L})$ in slides covered with a coverslip with a grid were incubated at $28^{\circ} \mathrm{C}(10 \mathrm{~min})$. At least 250 motile sperm were counted for 10 minutes and classified as bound motile sperm (BMS, adhered sperm head with vigorous tail movements) or not bound (FPMS, free progressive motile sperm). The effects of treatment on $\%$ HBS ([BMS / (FPMS+BMS)] x 100) and IMS were computed by ANOVA and differences among groups by post-hoc LSD. Correlation between IMS and HBS was calculated by the Pearson product-moment correlation coefficient method. The measure of variability of means is expressed by their standard errors. Significance was accepted at $\mathrm{p} \leq 0,05$.

\section{RESULTS}

Fresh ejaculates $(n=3)$ presented a mean volume of $1,08 \pm 0,19 \mathrm{~mL}$, a sperm concentration of $4,3 \pm 0,06 \times 10^{9} \mathrm{spz} \mathrm{mL}^{-1}$, a mass motility of 4 , an IMS of $63,3 \pm 3,3 \%$. 
The $\%$ HBS ofFS and CS-SM groups were similar $(\mathrm{p}=0,77)$, and both were significantly higher than those of CS-EY ( $p=0,0003$ for FS and $\mathrm{p}=0,0005$ for CS-SM) and FTS-EY $(p=0,0006$ for FS and $p=0,0009$ for CS-SM) groups (table I). Considering all groups, the $\%$ HBS was calculated from a total of 2156 motile sperm cells (table I). In FTS-EY, IMS was significantly lower than in all other groups $(\mathrm{p}=0,003$; table II). IMS was positive and significantly correlated with the $\%$ of HBS $(\mathrm{r}=0,62 ; \mathrm{p}=0,034)$ considering paired values from all groups $(\mathrm{n}=12)$, and is explained by the following regression equation: $\mathrm{HBS}=9,635$ $+0,855 \times$ IMS $(\mathrm{F}[1,10]=6,07 ; \mathrm{p}=0,034)$.

\section{DISCUSSION}

To our knowledge, this is the first time that a sperm-hyaluronan binding assay was tested in ram semen, either fresh, chilled or frozen, and diluted with different extenders. The values of $\%$ HBS obtained in the FS $(71,2 \%)$ and the CS $(73,6 \%)$, are close to the human semen (around $80 \%$ ). Those obtained after adding the freezing extender $(25 \%)$, which were not reduced after freezing $(29,7 \%)$, show

Table I. Hyaluronan binding assay: total motile sperm and percentages of hyaluronan bound sperm (HBS) from fresh (FS), chilled (CS-SM and CS-EY) and frozen-thawed (FTS$E Y)$ semen from three ejaculates. (Teste de ligação ao ácido hialurónico: total de espermatozóides móveis e percentagem de espermatozóides ligados ao ácido hialurónico (HBS) no sémen frasco (FS), refrigerado (CSSM e CSEY) e congelado (FTSEY) de três ejaculados).

\begin{tabular}{lcc}
\hline & \multicolumn{2}{c}{ HBA } \\
\cline { 2 - 3 } Groups & $\begin{array}{c}\text { Total motile } \\
\text { sperm }(\mathrm{n})\end{array}$ & HBS \% \pm SE \\
\hline From fresh & 779 & $73,62 \pm 3,34^{\mathrm{a}}$ \\
Chilled CS-SM & 467 & $71,15 \pm 10,34^{\mathrm{a}}$ \\
Chilled CS-EY & 638 & $25,00 \pm 3,30^{\mathrm{b}}$ \\
Frozen-thawed & 272 & $29,73 \pm 1,44^{\mathrm{b}}$ \\
ANOVA & & $\mathrm{p}=0,0004$ \\
\hline
\end{tabular}

$a \neq b: p<0,05$, LSD.
Table II. Individual motile sperm (IMS) from fresh (FS), chilled (CS-SM and CS-EY) and frozen-thawed (FTS-EY) semen from three ejaculates, evaluated after dilutions and previously to HBA tests. (Motilidade individual progressiva (IMS) no sémen fresco (FS), refrigerado (CSSM e CSEY) e congelado (FTSEY), de três ejaculados, após a diluição e antes do teste HBA).

\begin{tabular}{lc}
\hline Groups & IMS $(\%) \pm$ SE \\
\hline Fresh & $63,33 \pm 3,33^{\mathrm{a}}$ \\
Chilled CS-SM & $55,00 \pm 2,89^{\mathrm{a}}$ \\
Chilled CS-EY & $48,33 \pm 8,33^{\mathrm{a}}$ \\
Frozen-thawed & $21,67 \pm 4,41^{\mathrm{b}}$ \\
ANOVA & $\mathrm{p}=0,003$ \\
\hline
\end{tabular}

$a \neq b: p<0,05$, LSD.

that the extender, but not the freezing process itself, reduced the ability of sperm to bind hyaluronan. It is reasonable to state that the freezing extender constituent(s) may impair the binding of sperm membrane protein(s) to hyaluronan, decreasing sperm adhesion to the extracellular matrix in cervix and vagina, explaining the lower fertility rates when FTS is used, and the moderate increase of fertility rate in misoprostol treated ewes inseminated with FTS compared to the significant increase when CS was used (Barbas et al., 2013).

Our results show that, besides the ability of thawed sperm to swim across cervical mucus (Richardson et al., 2011), sperm-hyaluronan binding ability might be an important prerequisite for colonizing the genital tract with high numbers of viable sperm available for fertilization.

Differently from humans, where it is proposed the use of a protein enriched human tubal fluid medium for incubation of sperm prior and during the HBA, our results show that in the ram the only medium allowing sperm binding was $\mathrm{SOF}+$ glucose, denoting species differences.

An overall positive correlation of sperm motility with sperm-hyaluronan binding ability was observed in the present study, in agree- 


\section{MARQUES, BARBAS, HORTA, BAPTISTA, PEREIRA E CAVACO-GONÇALVES}

ment with results on human semen (Ghosh et al., 2002; Yagci et al., 2010).

Although needing confirmation on a larger number of animals, the freezing extender used in the present work disrupted the mechanism

\section{BIBLIOGRAPHY}

Bains, R.; Adeghe, J. and Carson, R.J. 2002. Human sperm cells express CD44. Fertil Steril, 78: 307-312.

Barbas, J.P.; Horta, A.E.M.; Marques, C.C.; Baptista, M.C.; Mascarenhas, R.D.; Martins, D.O.; Vasques, M.I.; Pereira, R.M. and Cavaco-Gonçalves, S. 2013. The fertility increase after misoprostol administration is differently expressed when sheep are inseminated with chilled or frozen-thawed semen. Small Ruminant Res, 113: 398-401.

Ghosh, I.; Bharadwaj, A. and Datta, K. 2002. Reduction in the level of hyaluronan binding protein 1 (HABP1) is associated with loss of sperm motility. J Repr Immunol, 53: 45-54.

Horta,A.E.M.; Barbas, J.P.; Marques, C.C.; Baptista, M.C.; Vasques, M.I.; Pereira, R.M.; Mascarenhas, R.D. and Cavaco-Gonçalves, S. 2010. Improvement of fertility in artificially inseminated ewes following vaginal treatment with misoprostol plus terbutaline sulphate. Reprod Dom Anim, 45: e412-e416.

Leethongdee, S.; Kershaw, C.M.; Scaramuzzi R.J. and Khalid, M. 2007. Misoprostol increases hyaIuronan in the sheep cervix. The Association of Clinical Embryologists, The British Fertility Society, The Society for Reproduction and Fertility (Ed.). Fertility 2007 Programme and Abstract Book. Biennial Joint Meeting of the UK Fertility Societies. University of York. York. 75 pp.

Marques, C.C.; Barbas, J.P.; Baptista, M.C.; Cannas Serra, C.; Vasques, M.I.; Pereira, R.M.; of sperm hyaluronan binding prior to the freezing-thawing process. This may explain the lower fertility rates obtained after transvaginal artificial insemination with FTS in this species.

Cavaco-Gonçalves, S. e Horta, A.E.M. 2006. Reproduction in the ovine Saloia breed: seasonal and individual factors affecting fresh and frozen semen performance, in vivo and in vitro fertility. Animal Products from the Mediterranean Area. Wageningen Academic (Publisher). Nederlands. 119: 331-336.

Richardson, L.; Hanrahan, J.P.; O'Hara, L.; Donovan, A.; Fair, S.; O'Sullivan, M.; Carrington, S.D.; Lonergan, P. and Evans, A.C.O. 2011. Ewe breed differences in fertility after cervical AI with frozen-thawed semen and associated differences in sperm penetration and physicochemical properties of cervical mucus. Anim Reprod Sci, 129: 37-43.

Tervit, H.R.; Whittingham, D.G. and Rowson, L.E.A. 1972. Successful culture in vitro of sheep and cattle ova. J Reprod Fertil, 30: 493-497.

Tollner, T.L.; Dong, Q. and VandeVoort, C.A. 2011. Frozen-thawed rhesus sperm retain normal morphology and highly progressive motility but exhibit sharply reduced efficiency in penetrating cervical mucus and hyaluronic acid gel. Cryobiology, 62: 15-21.

Yagci, A.; Murk, W.; Stronk, J. and Huszar, G. 2010. Spermatazoa bound to solidstate hyaluronic acid show chromatin structure with high DNA chain integrity: An acridine orange fluorescence study. J Androl, 31: 566-572.

Archivos de zootecnia vol. 63, núm. 244, p. 700. 